\title{
A new short-term toxicity assay using Aspergillus awamori with recombinant aequorin gene
}

\author{
Olga Kozlova*1,4, Mark Zwinderman ${ }^{2}$ and Nick Christofi ${ }^{3}$
}

\begin{abstract}
Address: ${ }^{1}$ Institute of Cell \& Molecular Biology, The University of Edinburgh, King's Buildings, Edinburgh, EH9 3JL, UK, ${ }^{2}$ Pollution Research Unit, Napier University, Merchiston Campus, Edinburgh, EH10 5DT, UK; Presently, Surfactant Technologies Ltd., C/o Avecia Fine Chemicals,, Grangemouth, FK3 8XG, UK, ${ }^{3}$ Pollution Research Unit, Napier University, Merchiston Campus, Edinburgh, EH10 5DT, UK and ${ }^{4}$ LUTESS Ltd., Orchard Brae House,, Edinburgh EH4 2HG, UK
\end{abstract}

Email: Olga Kozlova* - olga@lutess.com; Mark Zwinderman - markzwinderman@surfactanttechnologies.com;

Nick Christofi - n.christofi@napier.ac.uk

* Corresponding author

Published: 02 July 2005

BMC Microbiology 2005, 5:40 doi:10.1186/147/-2180-5-40
Received: 12 January 2005

Accepted: 02 July 2005

This article is available from: http://www.biomedcentral.com/I47I-2180/5/40

(c) 2005 Kozlova et al; licensee BioMed Central Ltd.

This is an Open Access article distributed under the terms of the Creative Commons Attribution License (http://creativecommons.org/licenses/by/2.0), which permits unrestricted use, distribution, and reproduction in any medium, provided the original work is properly cited.

\begin{abstract}
Background: Most currently available short-term toxicity assays are based on bacterial cells. Therefore there is a need for novel eukaryotic microbial bioassays that will be relevant to higher eukaryotes such as animals and plants. $\mathrm{Ca}^{2+}$ is a universal intracellular signalling molecule found in all organisms from prokaryotes to highly specialized animal cells. In fungi calcium has been demonstrated to be involved in control of many important processes. The recombinant aequorin gene from the jellyfish Aequorea victoria responsible for the expression of the $\mathrm{Ca}^{2+}$-sensitive aequorin photoprotein has been cloned in the filamentous fungus Aspergillus awamori. This has allowed real life monitoring of $\left[\mathrm{Ca}^{2+}\right]_{c}$ changes in living fungal cells. When subjected to different physico-chemical stimuli fungal cells respond by transiently changing the concentration of free $\mathrm{Ca}^{2+}$ in the cytosol $\left(\left[\mathrm{Ca}^{2+}\right]_{c}\right)$ and the pattern of these changes $\left(\mathrm{Ca}^{2+}\right.$ signature) is specific to each particular stimulus. Therefore it was interesting to investigate whether different environmental toxicants would be able to affect the pattern of $\left[\mathrm{Ca}^{2+}\right]_{c}$ changes in a reproducible and dose dependant manner.

Results: Toxicity bioassay has been developed to monitor changes $\left[\mathrm{Ca}^{2+}\right]_{c}$ of the recombinant fungus in the presence of toxicants representing heavy metals $-\mathrm{Cr}^{6+}$ and $\mathrm{Zn}^{2+}$ and a phenolic polar narcotic $-3,5-D C P$. The fungus responds to toxicants by a decrease in the amplitude of $\left[\mathrm{Ca}^{2+}\right]_{\mathrm{c}}$ response to $5 \mathrm{mM}$ external $\mathrm{CaCl}_{2}$ and an increase in $\mathrm{Ca}^{2+}$ final resting levels and recovery time.

Conclusion: A novel toxicity bioassay utilizing eukaryotic cells has been developed based on filamentous fungi transformed with the recombinant aequorin gene. A range of parameters characterising changes in $\left[\mathrm{Ca}^{2+}\right]_{\mathrm{c}}$ has been identified, e.g. Amplitude, Length of Transient, Final Resting Level and Recovery Time. These parameters can be used to determine the toxicity of a range of chemicals to eukaryotic cells in a 96-well microtitre plate method.
\end{abstract}

\section{Background}

The widespread use and release of natural and synthetic chemicals into the environment, singly or as complex domestic and industrial effluents, has necessitated the 
development of rapid and cost effective toxicity tests to protect humans and other biota [1,2]. Short-term and long-term bioassays exist utilising microorganisms, invertebrates and higher plants and animals. The short-term microbial toxicity tests involve bacteria, algae, protozoa and fungi (yeasts). One of the most widely used is the Microtox ${ }^{\oplus}$ proprietary test utilising a natural light emitting marine bacterium, Vibrio fischeri. $V$. fischeri is a gram negative free-living luminescent bacterium [3,4] also found in some species of fish and squid within the light organs [5].

Bioluminescence involves the emission of visible light mediated by the luciferin-luciferase enzyme system [6]. Microbial bioluminescence is a branch of the electron transport chain [7] and as electron transport is involved in cell metabolism, any disruption to this system e.g. by the presence of toxins, will have an effect on light output. Luminescence is controlled by the lux operon [8] within $V$. fischeri, which produces light at $490 \mathrm{~nm}[7,9]$.

Calcium is a well-known second messenger involved in the transduction of different external stimuli and hormonal signals in eukaryotic cells. A great number of studies describing changes in $\left[\mathrm{Ca}^{2+}\right]_{c}$ have been done describing the role of calcium in animal and plant cells subjected to different treatments. However, very little work in this area has been done on filamentous fungi due to the lack of both routine and reliable methods for monitoring intracellular free $\mathrm{Ca}^{2+}$ in living fungal cells.

Recently recombinant aequorin gene has been expressed in filamentous fungi [10]. Aequorin is a $\mathrm{Ca}^{2+}$-sensitive photoprotein of the jellyfish Aequorea victoria $(\mathrm{Mr}=$ $21,400)$ [11]. The protein consists of a single polypeptide chain, apoaequorin, a hydrophobic luminophore, coelenterazine and bound oxygen [12]. Once $\mathrm{Ca}^{2+}$ ions are bound to the three $\mathrm{Ca}^{2+}$-binding sites in aequorin, the protein is converted into an oxygenase. The oxygenase catalyses the oxidation of the substrate coelenterazine by the bound oxygen and this results in blue light emission. The amount of luminescence emitted by aequorin is dependent upon free $\mathrm{Ca}^{2+}$ concentration and thus aequorin can be used to report cytosolic $\mathrm{Ca}^{2+}\left(\left[\mathrm{Ca}^{2+}\right]_{\mathrm{c}}\right)$. Using aequorin transformed fungi it has been shown that different physico-chemical stimuli result in a transient $\left[\mathrm{Ca}^{2+}\right]_{\mathrm{c}}$ increases with a unique $\mathrm{Ca}^{2+}$ signature [10].

The general purpose of toxicity testing is to establish the potential impact of chemicals on biota in the environment. The information gained can then be used to manage the treatment or release of chemicals. Whether a substance is toxic or not depends on physico-chemical factors such as $\mathrm{pH}$, temperature and salinity, but most importantly on the test organism used, the concentration of the chemical and the conditions imposed for the test (see e.g. [13]. No single toxicity test can determine the effect of toxicants on all biota because of differences in response by organisms at different trophic levels. Eukaryotic organisms can behave differently to prokaryotes although with the $V$. fischeri test a high correlation has been shown with other bioassays using more complex organisms [14].

In this study we have tested the effect of toxic substances on the dynamics of $\left[\mathrm{Ca}^{2+}\right]_{\mathrm{c}}$ in the fungus Aspergillus awamori, containing aequorin gene that constitutively expresses the $\mathrm{Ca}^{2+}$-binding photoprotein aequorin. Data are compared with those obtained using the $V$. fischeri bioluminescence assay. This represents the first study in using recombinant aequorin genes in a filamentous fungus to assess toxicity of aqueous samples.

\section{Results}

All three toxicants tested showed a response (Table 1). Parameters assessed were rise time (characterises the time from application of stimulus to maximum amplitude of the response), amplitude (A), Length of Transient $\left(\mathrm{LT}_{50}\right.$ at the point where $\mathrm{A}=1 /{ }_{2} \mathrm{~A}_{\max }$ ), final resting level (level of $\left[\mathrm{Ca}^{2+}\right]_{\mathrm{c}}$ at the end of the experiment) and recovery time (luminescence integrated from the point when amplitude is maximal to the point when $\left[\mathrm{Ca}^{2+}\right]_{\mathrm{C}}$ reaches its final resting level at the end of the experiment.

At low concentration, 3,5-DCP (5 min preincubation) caused a small increase in the amplitude of the $\left[\mathrm{Ca}^{2+}\right]_{\mathrm{c}}$ response. At high concentrations (11.2 and $112 \mathrm{mgl}^{-1}$ ) the phenolic inhibited the amplitude of the $\left[\mathrm{Ca}^{2+}\right]_{\mathrm{C}}$ response at both 5 and 30 min preincubation (Figure 1a \&1b; Table $1)$. The highest concentration of 3,5-DCP $\left(112 \mathrm{mg} \mathrm{l}^{-1}\right)$ also increased $\mathrm{LT}_{50}$ and rise time (Table 1). At all three concentrations of 3,5-DCP there were elevated final resting levels of $\mathrm{Ca}^{2+}$ and increased recovery times. The percentage increase in the final resting levels and recovery time [15] were used as a quantifying parameter for the analysis of the effect of the phenolic toxicant on $\left[\mathrm{Ca}^{2+}\right]_{\mathrm{c}}$ (Table 1).

Chromium did not affect $(\mathrm{P}<0.5)$ the final resting levels and recovery time of $\mathrm{Ca}^{2+}$ but had a strong dose dependant inhibition of the amplitude of the $\left[\mathrm{Ca}^{2+}\right]_{\mathrm{c}}$ response (Figure 1c \&1d). Zinc had a combination of these effects on $\left[\mathrm{Ca}^{2+}\right]_{\mathrm{c}}$ (Figure 1e \&1f). It caused a decrease in amplitude of the $\left[\mathrm{Ca}^{2+}\right]_{\mathrm{c}}$ response as well as an increase in the final resting levels and recovery times at high concentrations ( $\geq 350 \mathrm{mg} \mathrm{l}^{-1}$ ) (Table 1 ). Both inhibition of the amplitude and the increase in the final resting levels were dose dependent with the exception of the $1300 \mathrm{mg} \mathrm{l}^{-1} \mathrm{Zn}^{2+}$ at $30 \mathrm{~min}$ preincubation. The increase of the above mentioned parameters observed at this concentration was lower than when fungi were treated with $700 \mathrm{mg} \mathrm{l}^{-1}$ of 
Table I: Detailed analysis of the effects of preincubating cultures of $A$. awamori with 3,5-DCP, $\mathrm{Cr}^{6+}$ and $\mathrm{Zn}^{2+}$ on $\left[\mathrm{Ca}^{2+}\right]_{\mathrm{C}}$ response to 5 mM external $\mathrm{CaCl}_{2}$

\begin{tabular}{|c|c|c|c|c|c|c|c|}
\hline \multirow[t]{2}{*}{ Toxicant } & & \multicolumn{6}{|c|}{ Features of $\left[\mathrm{Ca}^{2+}\right]_{C}$ Signatures } \\
\hline & & $A$ & $\mathrm{LT}_{50}$ & $\begin{array}{l}\text { FRL (\%) } 5 \text { min pre- } \\
\text { incubation }\end{array}$ & $\begin{array}{l}\text { RT (\%) } 5 \text { min pre- } \\
\text { incubation }\end{array}$ & $\begin{array}{l}\text { FRL (\%) } 30 \text { min pre- } \\
\text { incubation }\end{array}$ & $\begin{array}{l}\text { RT (\%) } 30 \text { min pre- } \\
\text { incubation }\end{array}$ \\
\hline $3,5-\mathrm{DCP}$ & 0.112 & $\uparrow$ & - & $\mathrm{III} \pm 8.4(\uparrow)$ & $|\mathrm{I}| \pm 8.4(\uparrow)$ & $106 \pm 7.6(-)$ & $98 \pm 1.3(-)$ \\
\hline \multirow[t]{2}{*}{$\left(\left.m g\right|^{-1}\right)$} & 11.2 & $\downarrow$ & - & $120 \pm 4.8(\uparrow)$ & $125 \pm 4.6(\uparrow)$ & $127 \pm 29.7(-)$ & $134 \pm 31.9(\uparrow)$ \\
\hline & 112 & $\downarrow$ & $\uparrow$ & $289 \pm 17.6(\uparrow)$ & $292 \pm 6.6(\uparrow)$ & $416 \pm 23.2(\uparrow)$ & $416 \pm 16.6(\uparrow)$ \\
\hline $\mathrm{Cr}^{6+}$ & 15 & $\downarrow$ & - & - & - & - & - \\
\hline \multirow[t]{2}{*}{$\left(\mathrm{mgl}^{-1}\right)$} & 120 & $\downarrow$ & - & - & - & - & - \\
\hline & 260 & $\downarrow$ & - & - & - & - & - \\
\hline $\mathrm{Zn}^{2+}$ & 180 & $\uparrow$ & - & $106 \pm 9.2(-)$ & $127 \pm 4.6(\uparrow)$ & $97 \pm 6.9(-)$ & $92 \pm 1.9(\downarrow)$ \\
\hline \multirow{3}{*}{$\left(\left.m g\right|^{-1}\right)$} & 350 & $\downarrow$ & - & $153 \pm 13.6(\uparrow)$ & $167 \pm 14.4(\uparrow)$ & $149 \pm 1 \mid .4(\uparrow)$ & $143 \pm 10.2(\uparrow)$ \\
\hline & 700 & $\downarrow$ & $\uparrow$ & $164 \pm 30.7(\uparrow)$ & $179 \pm 26.9(\uparrow)$ & $245 \pm 16.5(\uparrow)$ & $261 \pm 9.6(\uparrow)$ \\
\hline & 1300 & $\downarrow$ & $\uparrow$ & $169 \pm 14.8(\uparrow)$ & $182 \pm 10.4(\uparrow)$ & $169 \pm 12.6(\uparrow)$ & $176 \pm 16.5(\uparrow)$ \\
\hline
\end{tabular}

Note: - no effect compared with untreated control), $\uparrow$ increase in parameter, $\downarrow$ decrease in parameter, A - amplitude, LT $50-L$ Length of transient, FRL - Final $\mathrm{Ca}^{2+}$ resting level, $\mathrm{RT}$ - recovery time. $A$ and $\mathrm{LT}_{50}$ are shown only for 5 min incubation. Results represent mean $\pm S D$. The \% values represent the absolute value of the parameter not the relative increase compared with control. $N=6$

$\mathrm{Zn}^{2+}$. This was probably due to aequorin quenching which is known to be caused by the very high concentrations of some heavy metals. At low concentration ( $180 \mathrm{mg}$ $\left.\mathrm{l}^{-1}\right) \mathrm{Zn}^{2+}$ caused an increase in amplitude of the $\left[\mathrm{Ca}^{2+}\right]_{\mathrm{c}}$ response as well as an increase in the final $\mathrm{Ca}^{2+}$ resting level and recovery time.

Recovery of treated A. awamori to basal $\mathrm{Ca}^{2+}$ levels and light dissipation was fairly rapid in systems challenged with $\mathrm{Cr}^{6+}$ for 5 and $30 \mathrm{~min}$. This was not the case for $A$. awamori treated with $\mathrm{Zn}^{2+}$ and 3,5-DCP. In these cases there was protracted recovery in $\mathrm{Ca}^{2+}$ content at higher toxicant challenges with both 5 and 30 min incubation.

$\mathrm{IC}_{50}$ is one standard parameter calculated in toxicity studies and was chosen in this study to determine differences in values obtained by the fungal and bacterial luminescence bioassays. In order to calculate $\mathrm{IC}_{50}$ values for all toxicants it was decided to utilise the amplitude of $\left[\mathrm{Ca}^{2+}\right]_{\mathrm{c}}$ changes in the fungal cell after challenge with different concentrations of toxicant. Examples of dose response curves are presented in Figures 2, 3. Calculated $\mathrm{IC}_{50}$ values for the 5 and 30 min toxicant pre-incubations with $A$. awamori are presented in Table 2 . The $30 \mathrm{~min}^{\mathrm{IC}_{50}}$ for DCP, $\mathrm{Cr}^{6+}$ and $\mathrm{Zn}^{2+}$ are 36.7, 167.8 and $549.7 \mathrm{mg} \mathrm{l}^{-1}$ respectively. These can be compared to values for the $V$. fischeri test of results of 3.6, 13.95 and $0.44 \mathrm{mg} \mathrm{l}^{-1}$ for the same toxicants tested over a $30 \mathrm{~min}$ incubation period.

\section{Discussion}

In this paper data have been presented on the response of A. awamori to different toxicant concentrations by examining changes in Relative Light Units (RLU) and $\left[\mathrm{Ca}^{2+}\right]_{C}$ in the presence of an external $\mathrm{CaCl}_{2}$ concentration of $5 \mathrm{mM}$. This study differs from that of Torrecilla et al. [16] which examined changes in intracellular $\mathrm{Ca}^{2+}$ of the cyanobacterium Anabaena able to express apoaequorin constitutively when subjected to heat and cold shock. It is also the first study, as far as we know, examining responses of aequorin to toxicants in a filamentous fungus. The concentrations of $\mathrm{Zn}^{2+}, \mathrm{Cr}^{6+}$ and 3,5-DCP used in the experiments to assess toxicity were based on experience with $V$. fischeri bioassays, through range finding and interest in observing effects at low and high concentrations. Initially, the effect of each of these three chemicals on $\left[\mathrm{Ca}^{2+}\right]_{c}$ was examined. The $\left[\mathrm{Ca}^{2+}\right]_{\mathrm{C}}$ response was not significantly different from that obtained with the control solution (data not shown). A second approach studied the effect of preincubation of the fungus with toxicants on $\left[\mathrm{Ca}^{2+}\right]_{\mathrm{c}}$ response to external $\mathrm{CaCl}_{2}$.

There is no doubt that aequorin transformed A. awamori, using the protocol developed, responds to toxic chemical challenge in a reproducible way. The aequorin system has more parameters which can be assessed than other bioassays i.e. final $\left[\mathrm{Ca}^{2+}\right]_{\mathrm{C}}$ resting level, recovery time and amplitude of $\left[\mathrm{Ca}^{2+}\right]_{c} / \mathrm{RLU}$ following chemical challenge for 5 or $30 \mathrm{~min}$.

A. awamori has been shown to respond to organic and inorganic compounds by a decrease in the amplitude of $\left[\mathrm{Ca}^{2+}\right]_{\mathrm{C}}$ response to external $\mathrm{CaCl}_{2}$ with increasing toxicant concentration. $\mathrm{Zn}^{2+}$ and DCP also affected the final $\mathrm{Ca}^{2+}$ resting levels and recovery times. In the case of $30 \mathrm{~min}$ preincubation with either $112 \mathrm{mg} \mathrm{l}^{-1}$ DCP or $700 \mathrm{mg} \mathrm{l}^{-1}$ $\mathrm{Zn}^{2+}$, the final $\left[\mathrm{Ca}^{2+}\right]_{\mathrm{C}}$ resting levels remained significantly 


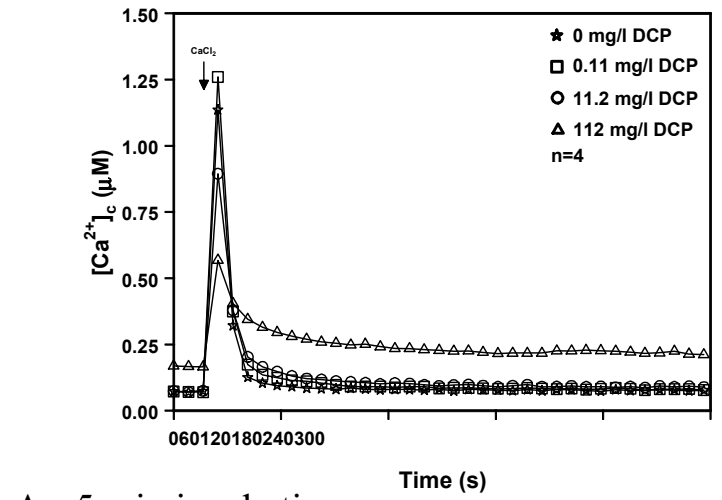

A - 5 min incubation

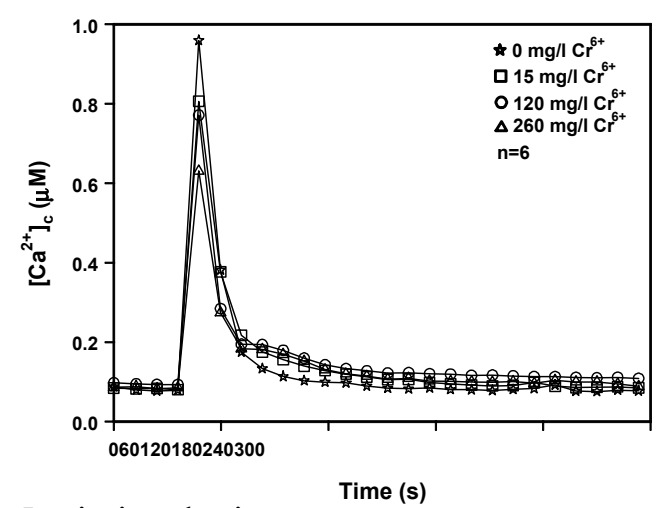

C - 5 min incubation

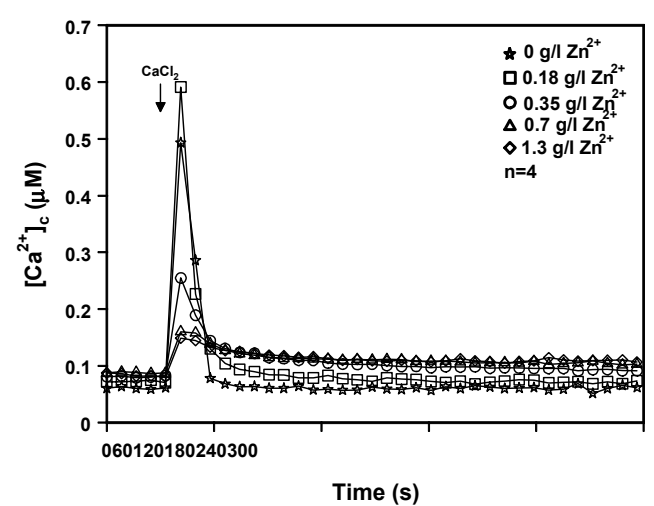

E- 5 min incubation

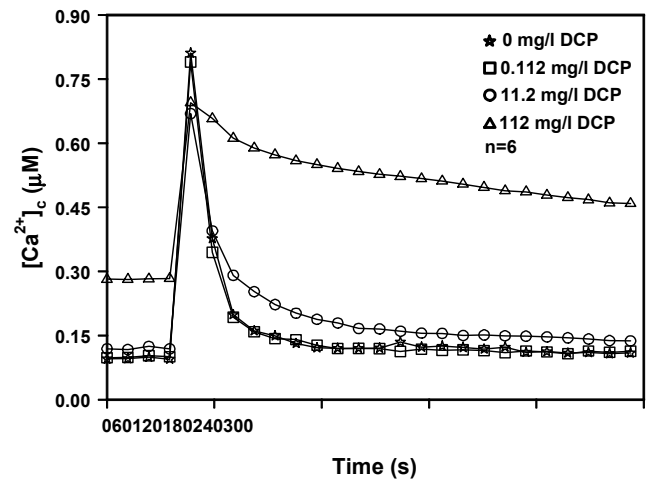

B - 30 min incubation

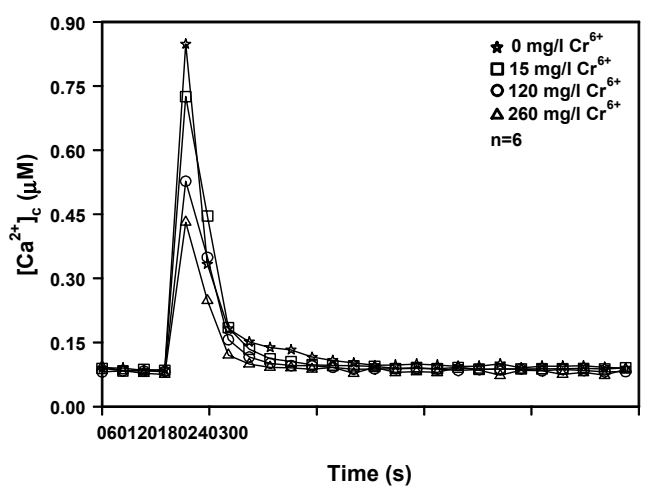

D - 30 min incubation

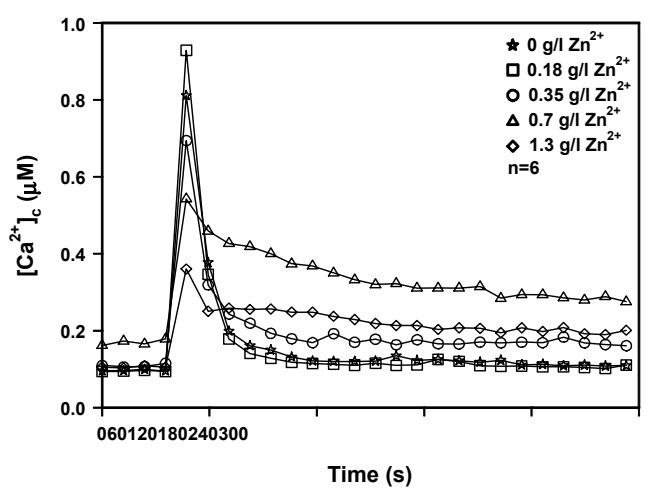

F - 30 min incubation

\section{Figure I}

Effect of 3,5-DCP, $\mathrm{Cr}^{6+}$ and $\mathrm{Zn}^{2+}$ on $\left[\mathrm{Ca}^{2+}\right]_{\mathrm{c}}$ response to the addition of external $\mathrm{CaCl}_{2}(5 \mathrm{mM})$. A, C and $\mathrm{E}$ show 5 min incubation with the toxicant, B, D F show 30 min incubation with the toxicant. 


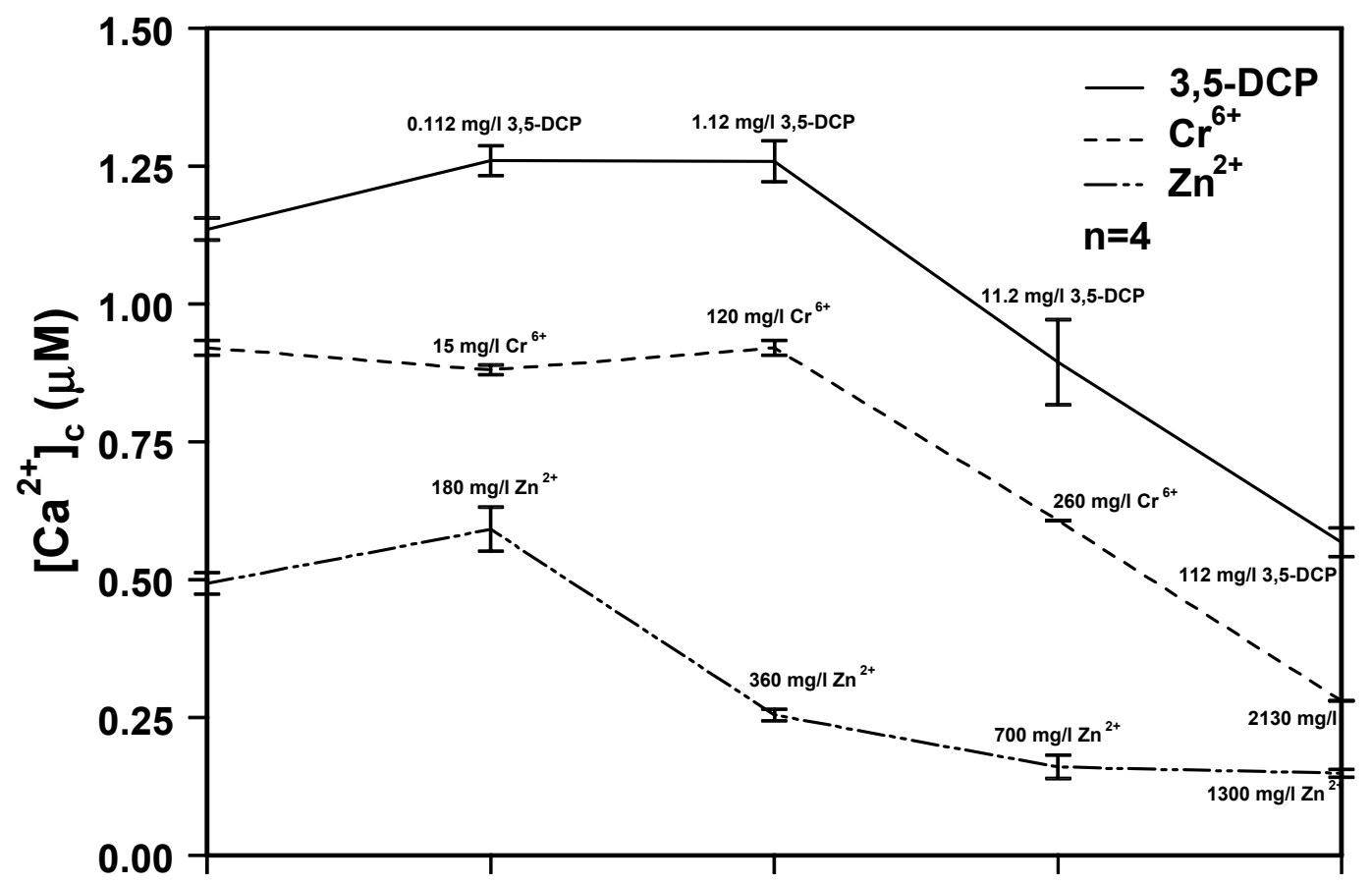

\section{Figure 2}

Effect of 3,5-DCP, $\mathrm{Cr}^{6+}$ and $\mathrm{Zn}^{2+}$ on amplitude of $\left[\mathrm{Ca}^{2+}\right]_{c}$ in A. awamori 5 minute incubation.

higher than after 5 min preincubation with these toxicants indicating a greater toxicity to the fungus on longer contact with the toxicant. This is not an unusual response even in the $V$. fischeri bioassay where it is generally observed that toxicity increases ( $\mathrm{IC}_{50}$ values decrease) with longer incubation times. $\mathrm{IC}_{50}$ values calculated using amplitude changes of $\left[\mathrm{Ca}^{2+}\right]_{c}$ showed decreased toxicity to $\mathrm{Zn}^{2+}$ at longer preincubation times. This needs further analytical consideration to determine toxicity values of relevance.

The proprietary Microtox bioassay and other bacterial bioluminescence methods, including that used in the present study, which do not involve genetically modified bacteria, utilise Vibrio (e.g. V. fischeri) and related Photobacterium species. Acute toxicity tests utilising such luminescent bacteria can underestimate the toxicity of chemicals and Backhaus et al. [17] showed that more reliable toxicity estimates can be obtained through the use of long-term toxicity testing with the same organisms. It may be pru- dent to test the response of A. awamori using longer preincubation times with toxicants e.g. $>24 \mathrm{~h}$, prior to monitoring $\mathrm{Ca}^{2+}$ homeostasis. This may increase the sensitivity of the bioassay. It must be remembered however that for one of the toxicants ( $\left.\mathrm{Zn}^{2+}\right)$, a decrease in sensitivity was evident at $30 \mathrm{~min}$ compared to the result at $5 \mathrm{~min}$. There was also evidence of toxicity recovery through adaptation with increased incubation. This may be due to acquired resistance by the organism through synthesis of metal-binding proteins (metallothioneins) or constituents in the growth medium removing/immobilising the metal (e.g. EDTA, phosphate precipitation). This needs to be examined in the fungal bioassay.

It is interesting to compare toxicity data obtained with $A$. awamori with those obtained with the $V$. fischeri bioassay. The toxicity values for the fungus are higher than those of the bacterial test indicating lower bioassay sensitivity with the parameter used to calculate the $\mathrm{IC}_{50}$ values. For example, the $\mathrm{IC}_{50}$ values for the $30 \mathrm{~min} \mathrm{Zn}^{2+}$ incubations 


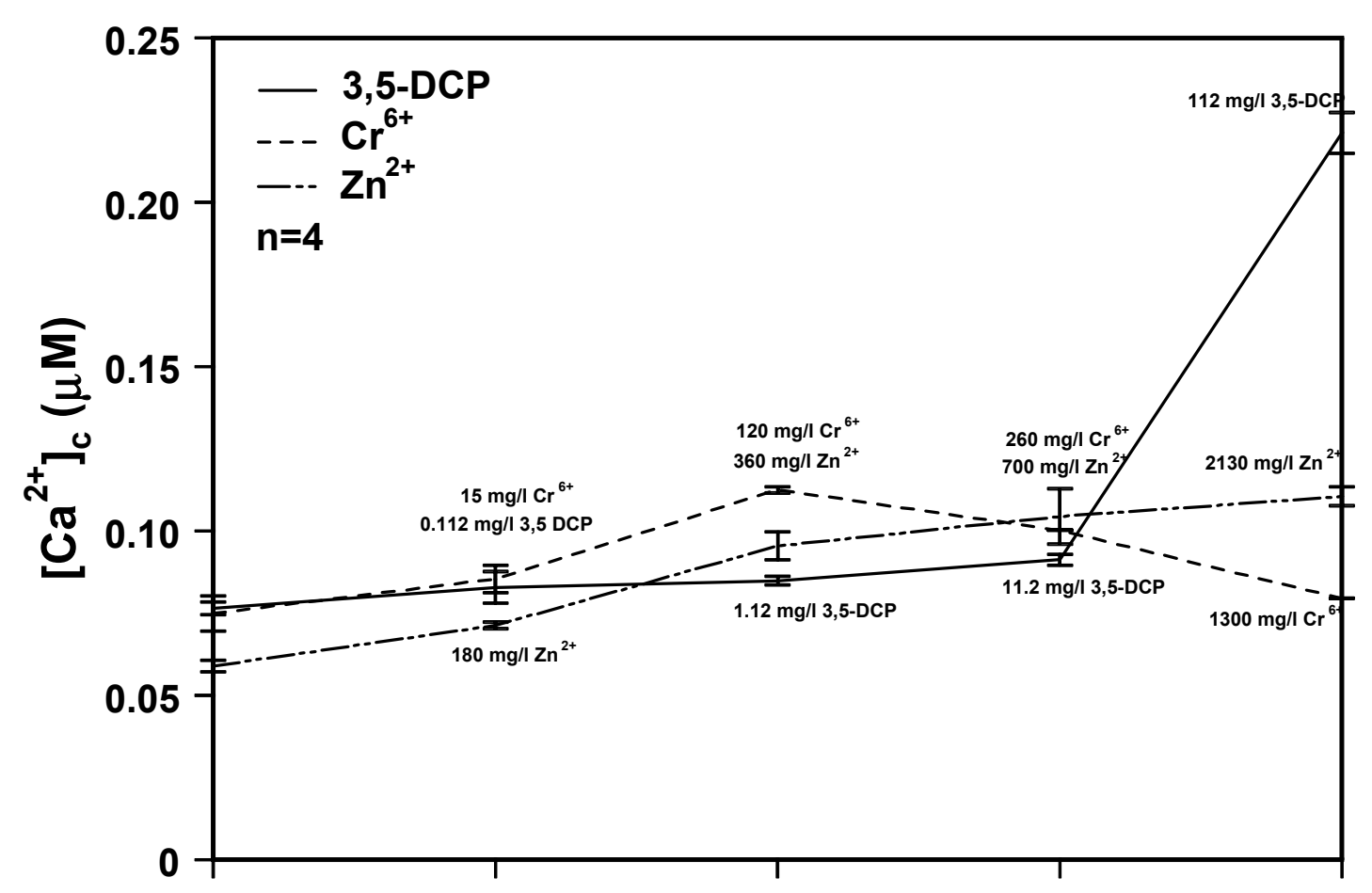

Figure 3

Effect of 3,5-DCP, $\mathrm{Cr}^{6+}$ and $\mathrm{Zn}^{2+}$ on final resting level of $\left[\mathrm{Ca}^{2+}\right]_{c}$ in $\mathrm{A}$. awamori 5 minute incubation.

Table 2: $\mathrm{IC}_{50}$ values $\left(\mathrm{mgl}^{-1}\right)$ for 3,5-DCP, $\mathrm{Cr}^{6+}$ and $\mathrm{Zn}^{2+}$ using V. fischeri and A. awamori, (based on amplitude of $\left.\left[\mathrm{Ca}^{2+}\right]_{\mathrm{c}}\right)$

\begin{tabular}{lllll}
\hline Treatment & V.fischeri & A. awamori & \\
\hline $\begin{array}{l}\text { Test duration or } \\
\text { preincubation time }\end{array}$ & $\mathrm{IC}_{50}(5 \mathrm{~min})$ & $\mathrm{IC}_{50}(30 \mathrm{~min})$ & $\mathrm{IC}_{50}(6 \mathrm{~min})$ & $\mathrm{IC}_{50}(30 \mathrm{~min})$ \\
\hline $3,5-\mathrm{DCP}$ & & & & 36.7 \\
$\mathrm{Cr}{ }^{6+}$ & 3.62 & 3.13 & 46.7 & 167.9 \\
$\mathrm{Zn}^{2+}$ & 29.9 & 13.95 & 400.1 & 549.7 \\
\hline
\end{tabular}

Note: $N=6$

were approximately 3 orders of magnitude lower for $V$. fischeri. Such insensitivity to $\mathrm{Zn}^{2+}$ has been observed with an ATP luminescence assay [18]. The $\mathrm{IC}_{50}$ results with $\mathrm{Cr}^{6+}$ (30 min preincubation) were $400 \mathrm{mg} \mathrm{l}^{-1}, 12$ times higher than in the bacterial biosensor. This value is the same order of magnitude as the 15 min Microtox assay (339.6 $\mathrm{mg} \mathrm{l}^{-1}$ ) carried out by Codina et al. [19]. Indeed, the use of $V$. fischeri in various proprietary tests (LumisTox, Microtox, ToxAlert etc) have been shown to exhibit differences in sensitivity to different toxicants [20]. It is, therefore, dif- 
ficult to categorically state that $V$. fischeri is more sensitive to $\mathrm{Cr}^{6+}$ than A. awamori particularly when different incubation periods are used in bioassays affecting any ultimate $\mathrm{IC}_{50}$ value. It should be also noted that since the aequorin test is based on changes in $\left[\mathrm{Ca}^{2+}\right]_{\mathrm{C}^{\prime}}$ toxic chemicals often exert an increase in $\left[\mathrm{Ca}^{2+}\right]_{\mathrm{C}}$ thus affecting $\mathrm{IC}_{50}$ calculations. The calculation of $\mathrm{IC}_{50}$ for this fungal bioassay may not be appropriate. Other parameters such as $\mathrm{LT}_{50}$, rise time, final $\mathrm{Ca}^{2+}$ resting levels and recovery time would provide ideal candidate parameters, but more tests and comparisons with other bioassays are needed. The aequorin bioassay can also generate up to 15 parameters to assess the effect of toxicants due to the complex pattern of $\left[\mathrm{Ca}^{2+}\right]_{\mathrm{c}}$ changes [21]. These parameters can be further used to create a profile for toxicants with specific modes of action [15]. With different parameters available for analysis in the aequorin test it could be useful to assess the toxicity by calculating the NOEC (no observable effect concentration) or a nominal $\mathrm{IC}_{10}$ value [22].

Codina et al. [19] also used a yeast bioassay to test metal toxicity. The eukaryotic yeast was found to be less sensitive to metals than prokaryotic organisms including Vibrio and Pseudomonas species. An $\mathrm{IC}_{50}$ value of $549.1 \mathrm{mg} \mathrm{l}^{-1}$ was obtained for $\mathrm{Zn}^{2+}$ using the yeast assay [19] which is comparable to some of the values obtained with $A$. awamori in our study. The yeast was slightly more sensitive to $\mathrm{Cr}^{6+}$ ( $30.9 \mathrm{mg} \mathrm{l}^{-1}$ ) than the filamentous $A$ awamori but this is not unusual among members of the same trophic level (see [19]. Recent chronic toxicity studies have been using wild-type and genetically modified mutants of the yeast Saccharomyces cerevisiae [23]. $\mathrm{EC}_{50}$ values of $>1000 \mathrm{mg} \mathrm{l}^{-1}$ were determined for $\mathrm{Zn}^{2+}$ and 1.7-4.79 $\mathrm{mg} \mathrm{l}^{-1}$ for $\mathrm{Cr}^{6+}$ indicating variability in assays that rely on conditions imposed including exposure time, species tested and criteria used in the final assessment.

An interesting observation is the enhanced stimulation of light output in some systems with a low concentration of toxicant. This is seen in the $5 \mathrm{~min}$ treated systems using $0.11 \mathrm{mg} \mathrm{l}^{-1}$ DCP (Figure 1a), $180 \mathrm{mg} \mathrm{l}^{-1} \mathrm{Zn}^{2+}$ (Figure 1e) and also in the $30 \mathrm{~min}$ treated system with $180 \mathrm{mg} \mathrm{l}^{-1} \mathrm{Zn}^{2+}$ (Figure 1f). This stimulation, referred to as hormesis, is a common occurrence in toxicity bioassays [13] and is often observed in our laboratory using the $V$. fischeri bioassay.

It is not clear based on these preliminary observations what causes $\mathrm{Ca}^{2+}$ and light retention. In the case of DCP it may be that this polar narcotic is affecting membrane permeability and the transport of $\mathrm{Ca}^{2+}$ out of the cytosol $\left(\mathrm{Ca}^{2+}\right.$ ATPase and efflux of $\mathrm{Ca}^{2+}$ via e.g. $\mathrm{Ca}^{2+} / \mathrm{H}^{+}$antiporters) and hence, a delay in RLU dissipation. The metals may be competing with the transport mechanisms in membranes. The metals thus act by interacting with phys- iological ions affecting transport and its concomitant effect on light output.

Most of the organic chemicals discharged to the environment exert a narcotic effect on biota. This is either Type I (non-polar narcosis) or Type II (polar narcosis). It would be interesting to utilise A. awamori to test whether nonpolar and polar narcoses operate in the fungus and whether these can be predicted by QSAR (Quantitative Structure Activity Relationships). Cronin and Schulz [24] showed, using QSAR, that non-polar narcosis occurs in $V$. fischeri but they could not validate polar narcosis in the organism.

There is no doubt that a comprehensive testing of metals and organic compounds needs to be carried out to assess the value of A. awamori as a toxicity sensing tool both in systems using pure chemicals and those involving real samples (e.g. complex effluents and soil water matrices). Toxicant preincubation time and effect on fungus response would be an important factor to test fully.

\section{Conclusion}

The current paper presents the proof-of-concept study of the novel toxicity bioassay based on using filamentous fungi transformed with the recombinant aequorin gene. The research conducted has shown that the recombinant aequorin method can be used as a novel eukaryotic toxicant biosensor. It offers more parameters which can be readily analysed than the traditionally used bacterial biosensors. The fungal aequorin biosensor responded to toxic substances $\left(3,5-\mathrm{DCP}, \mathrm{Zn}^{2+}\right.$ and $\left.\mathrm{Cr}^{6+}\right)$ by a decrease in the amplitude of the $\left[\mathrm{Ca}^{2+}\right]_{\mathrm{c}}$ response to $5 \mathrm{mM} \mathrm{CaCl}_{2}$ and an increase in the $\left[\mathrm{Ca}^{2+}\right]_{\mathrm{c}}$ resting levels $\left(\mathrm{Zn}^{2+}\right.$ and 3,5-DCP). Preliminary $\mathrm{IC}_{50}$ values obtained with the fungal aequorin system, and based on the inhibition of the $\left[\mathrm{Ca}^{2+}\right]_{\mathrm{C}}$ amplitude in response to external $\mathrm{CaCl}_{2}$ treatment, indicate that it is less sensitive for detecting 3,5-DCP, $\mathrm{Zn}^{2+}$ and $\mathrm{Cr}^{6+}$ than the $V$. fischeri luciferase system. However, it is obvious that the changes in amplitude is not the most suitable parameter for calculating $\mathrm{IC}_{50}$ and more research are needed to determine the best possible set of parameters to be used together with the aequorin bioassay.

\section{Methods \\ Chemicals}

Unless otherwise stated all the chemicals used were from Calbiochem-Novabiochem (UK) Ltd. (Nottingham, UK) or Sigma (Dorset, UK).

\section{Organisms and media}

Experiments were carried out with the strain of A. awamori $66 \mathrm{~A}$, which has been transformed with the recombinant aequorin gene [10]. All media and salt solutions were made up in distilled $\mathrm{H}_{2} \mathrm{O}$ and sterilised by autoclaving at 
$121^{\circ} \mathrm{C}$ at 15 psi for $20 \mathrm{~min}$ prior to use. A. awamori cultures were grown in liquid Vogel's medium with $1 \%$ sucrose (VS medium [25]).

A method of growing A. awamori cultures for in vivo luminometry was employed utilising static liquid culture in 96-well plates. Twelve $\mathrm{ml}$ of sterile VS medium was inoculated with $1 \times 10^{5}$ spores per $\mathrm{ml}$. Coelenterazine (Biosynth AG, Staad, Switzerland) was dissolved in methanol $(\mathrm{MeOH})$ to a final concentration of $2.5 \mu \mathrm{M}$. The final $\mathrm{MeOH}$ concentration was not more than $0.1 \%$, which has been shown not to affect spore germination or hyphal growth. Using a 12-channel pipette (Anachem, Luton, UK), $100 \mu \mathrm{l}$ of the inoculated medium was added to each well, and the plate covered with a microplate lid (Labsystems, Helsinki, Finland). Cultures were incubated in a humidity chamber in the presence of free water at $30^{\circ} \mathrm{C}$ for $24 \mathrm{~h}$.

Luminometry was performed using an EG \& G Berthold (Bad Wildbad, Germany) LB96P Microlumat luminometer. The luminometer was designed to measure luminescence using the flat-bottomed 96-well microtitre plates from EG\&G Berthold or Dynex Technologies Inc. (Chantily, UK). Two $100 \mu$ l built-in injectors allowed stimulation of samples.

The luminometer measures light emission in relative lights units (RLU). To convert RLU into $\left[\mathrm{Ca}^{2+}\right]_{C}$ concentrations the following empirically derived equation was used:

$\mathrm{pCa}=0.332588(-\log \mathrm{k})+5.5593$,

where $\mathrm{k}=$ luminescence counts $\mathrm{s}^{-1} /$ total luminescence counts [26].

Total luminescence is measured as an integral of all luminescence up to complete aequorin discharge. Aequorin was discharged by adding $2 \mathrm{M} \mathrm{CaCl}_{2}$ in $20 \%$ ethanol to the wells. Ethanol was used as a permeabilising agent. Conversion of RLU into $\left[\mathrm{Ca}^{2+}\right]_{c}$ concentration was made using a Macro developed in Excel 7.0 by Mark Knight (University of Oxford).

Three toxicants were tested: 3,5-DCP, $\mathrm{ZnSO}_{4}$ and $\mathrm{K}_{2} \mathrm{Cr}_{2} \mathrm{O}_{7}$. All toxicants were added $5 \mathrm{~min}$ and $30 \mathrm{~min}$ before treatment with $5 \mathrm{mM}$ external $\mathrm{CaCl}_{2}$ in a total volume of $25 \mu \mathrm{l}$ VS medium. 4-6 replicates were performed for each treatment. All the experiments were performed in triplicate. $\mathrm{IC}_{50}$ values were calculated only for the amplitude of the response.

Vibrio fischeri bioassays utilised cultures of the organism grown in Photobacterium Broth (PB) at $37^{\circ} \mathrm{C}$ until opti- mum light output. A $100 \mu \mathrm{l}$ volume of $V$. fischeri suspension was added to each of the 96 wells in a microtitre plate. During the experiment a $100 \mu \mathrm{l}$ volume of $\mathrm{NaCl}$ solution (giving a final concentration of $2 \% \mathrm{NaCl}$ in the test) containing the test substance in the appropriate concentration was added to the wells. For each measurement a control consisting of 6 wells with $V$. fischeri to which the $\mathrm{NaCl}$ solution was added. Chemicals were tested in five different concentrations and each concentration was tested in three replicates. Plates were measured in an Anthos Lucy 1 luminometer. Measurements were made over a period of $30 \mathrm{~min}$. $\mathrm{IC}_{50}$ values were calculated for 5 and $30 \mathrm{~min}$ incubations. Recording of data started immediately after addition of the test solutions to the wells containing the culture. The standard proprietary Microtox bioassay was also carried out [27].

\section{Authors' contributions}

OK conceived the study, designed and developed aequorin bioassay, carried out the tests and has been involved in the writing of the article.

$\mathrm{MZ}$ has designed the microbial part of the testing and participated in carrying out the fungal tests.

NC helped design the study and participated in writing of the article.

All authors read and approved the final manuscript.

\section{Acknowledgements}

We are grateful to Dr Mark Knight, Department of Plant Science, University of Oxford for the Excel 7.0 spreadsheet used to convert RLU to $\left[\mathrm{Ca}^{2+}\right]_{c}$ concentrations, University of Edinburgh for providing aequorin transformed fungi and to Darwin Trust for providing funding for Olga Kozlova.

\section{References}

I. Dalzell DJB, Alte S, Aspichueta E, de la Sota A, Etxebarria J, Gutierrez M, Hoffmann CC, Sales D, Obst U, Christofi N: A comparison of five rapid direct toxicity assessment methods to determine toxicity of pollutants to activated sludge. Chemosphere 2002, 47:535-545.

2. Sherry J, Scott B, Dutka B: Use of various acute, sublethal and early life-stage tests to evaluate the toxicity of refinery effluents. Environ Toxicol Chem 1997, 16:2249-2257.

3. Gellert G, Stomme A, Trujillano A: Development of an optimal bacterial medium based on the growth inhibition assay with V. fischeri. Chemosphere 1999, 39:467-476.

4. Hoffmann CC, Sales D, Christofi N: Combination ecotoxicity and testing of common chemical discharges to sewer using the Vibrio fischeri luminescence bioassay. Int Microbiol 2003, 6:4 I-47.

5. Ruby E, Lee K: The Vibrio fischeri-Euprymna scolopes light organ association: Current ecological paradigms. Appl Environ Microbiol 1998, 64:805-813.

6. Steinberg S, Poziomek E, Engelmann W, Rogers K: A review of environmental applications of bioluminescent measurement. Chemosphere 1995, 30:2155-2197.

7. Wilson T, Hastings JW: Bioluminescence. Ann Rev Cell Dev Biol 1998, I4:197-230.

8. Meighen E: Molecular-biology of bacterial bioluminescence. Microbiol Rev 1991, 55:|23-142. 
9. Hastings J, Potrikus C, Guptas S, Kurfust M, Makemson J: Biochemistry and physiology of bioluminescent bacteria. Adv Microb Physiol 1985, 26:235-291.

10. Nelson G, Kozlova-Zwinderman O, Collis AJ, Knight MR, Fincham JRS, Stanger CR, Renwick A, Hessing JGM, Punt PJ, van den Hondel CAMJ], Read ND: Calcium measurement in living filamentous fungi expressing codon-optimized aequorin. Molecular Microbiology 2004, 52: 1437-I450.

II. Nakajimashimada J, lida H, Tsuji FI, Anraku Y: Galactose-dependent expression of the recombinant ca-2+-binding photoprotein aequorin in yeast. Biochem Biophys Res Comm I99I, I 74: II5-I22.

12. Knight M, Campbell AK, Smith SM, Trewavas A: Recombinant aequorin as a probe for cytosolic free $\mathrm{Ca}^{2+}$ in Escherichia coli. FEBS Lett |99|, 282:405-405.

13. Christofi N, Hoffmann C, Tosh L: Hormesis responses in free and immobilised light-emitting bacteria. Ecotoxicol Environ Saf 2002, 52:227-23I.

14. Kaiser KLE: Qualitative and quantitative relationships of Microtox data with toxicity data for other aquatic species. In Ecotoxicology Monitoring Edited by: Richardson ML. Weinheim: VCH Publishers; 1993:197-21I.

15. Kozlova-Zwinderman O: Eukaryotic biosensor making use of a calcium regulated light emitting enzyme. PCT Patent WO2004050905 2004.

16. Torrecilla I, Leganés F, Bonilla I, Fernández-Pinas F: Use of recombinant aequorin to study calcium homeostasis and monitor calcium transients in response to heat and cold shock in cyanobacteria. Plant Physiol 2000, I 23:161-175.

17. Backhaus T, Froehner K, Altenburger R, Grimme LH: Toxicity testing with $V$. fischeri : A comparison between long term ( $24 \mathrm{~h})$ and the short term (30 min) bioassay. Chemosphere 1997, 35:2925-2938.

18. Dalzell DJB, Christofi N: An ATP luminescence method for direct toxicity assessment of pollutants impacting on the activated sewage sludge process. Water Research 2002, 36: I493-I502.

19. Codina JC, Pérez-Garcia A, Romero P, de Vicente A: A comparison of microbial bioassays for the detection of metal toxicity. Arch Environ Contam Toxicol 1993, 25:250-254.

20. Christofi N, Dalzell D, Hoffmann C, Sales D, Morton J, Arretxe M, Heap M, Obst U, Alte S, Etxebarria J, de Las Fuentes M, Gutierrez M, de la Sota A, Aspichueta E: DTOX- Direct toxicity assessment of complex industrial effluents discharged to sewer. Final Report to the European Commission. Contract SMT4-CT96-2084. Brussels: Project funded under the Standards, Measurements and Testing Programme 2000.

21. Kozlova-Zwinderman O: Calcium measurements in filamentous fungi using recombinant aequorin. In PhD Thesis University of Edinburgh, Institute of Cell and Molecular Biology; 2002.

22. Hoekstra JA, van Ewijk PH: The bounded effect concentration as an alternative to the NOEC. Sci Total Environ 1993, Part I(Suppl):705-7II.

23. Schmitt M, Gellert G, Ludwig J, Lichtenberg-Frate H: Phenotypic yeast growth analysis for chronic toxicity testing. Ecotoxicol Environ Saf 2004, 59:142-150.

24. Cronin MTD, Schulz TW: Validation of Vibrio fischeri acute toxicity data: mechanism of action-based QSARs for non-polar narcotics and polar narcotic phenols. Sci Total Environ 1997, 204:75-88.

25. Vogel HJ: A convenient growth medium for Neurospora (Medium N). Microbial Genetics Bulletin 1956, 5 I:107-124.

26. Fricker MD, Plieth $\mathrm{C}$, Knight H, Blancaflor E, Knight MR, White NS, Gilroy S: Fluorescence and Luminescence Techniques to Probe Ion Activities in Living Plant Cells. In Fluorescent and Luminescent Probes Edited by: Mason WT. London: Academic Press; 1999:569-596.

27. AZUR Environmental: Microtox Manual Carlsbad; 1997.

\section{Publish with BioMed Central and every} scientist can read your work free of charge

"BioMed Central will be the most significant development for disseminating the results of biomedical research in our lifetime. "

Sir Paul Nurse, Cancer Research UK

Your research papers will be:

- available free of charge to the entire biomedical community

- peer reviewed and published immediately upon acceptance

- cited in PubMed and archived on PubMed Central

- yours - you keep the copyright

Submit your manuscript here:

http://www.biomedcentral.com/info/publishing_adv.asp
BioMedcentral 